\title{
A Case Study on the Effect of Vocabulary Intervention Program Based on Morphological Awareness of Children with Language Learning Disability
}

\author{
Ji-yeong Oh, Kyunghee Jung \\ Department of Speech and Language Pathology, Graduate School of Rehabilitation and Welfare, Yongin University, Yongin, Korea
}

\author{
Received: September 28, 2020 \\ Revised: November 19, 2020 \\ Accepted: December 21, 2020

Correspondence:
Kyunghee Jung, PhD
Department of Speech and
Language Pathology,
Graduate School of Rehabilitation and
Welfare, Youngin University,
134 Yongindaehak-ro, Cheoin-gu,
Yongin 17092, Korea
Tel: +82-31-8020-2864
Fax: +82-31-8020-3390
E-mail: 1012jkh@hanmail.net

The purpose of this study was to investigate the effect of morphological awareness-based vocabulary interventions on vocabulary in children with language learning disabilities. The participants were three children with language learning disabilities, the evaluation procedure was pre-tested before intervention and post-tested after intervention. Two weeks after post-testing, a maintenance test was conducted. The task was used to find out the change in quantitative and qualitative vocabulary, morphological awareness, and multimorphemic words definition ability. The intervention program was produced by based on prior research and consisted of five stages: listening, sorting, morpheme detaching and adding, using strategies based on the meaning of the target words in the context, and making vocabulary dictionaries. The morphological awareness-based vocabulary intervention program had a positive effect on the quantitative and qualitative vocabulary and morphological awareness skills of children with language learning disabilities. The morphological awareness-based vocabulary intervention program, is an effective teaching strategy for children with language learning disabilities.

Key Words: Intervention, Language learning disability, Morphological awareness, Voabulary.

\section{INTRODUCTION}

학령기가 되면 언어 능력 중 특히 상위언어 능력(metalinguistic)의 중요성이 강조된다. 상위언어 능력이란 언어에 관해 사고할 수 있는 능력을 나타내는 것이다(Jeon, 1996). 상위언어 능력은 학령전기에 시작하고 학령기가 되면 탈중심성이 발달 하여 메시지의 의미와 언어적 정확성에 주의를 기울이면서 동 시에 처리를 할 수 있다(Owens, 2012). 학령기에는 의미 영역에 서 어휘의 양적인 측면이 주로 고려되는 학령전기에 비해 이미 습득한 어휘들을 서로 연관지어 가면서 의미를 보다 넓고 깊게 확장해 나가게 된다(Lee, 2007). 학령기에는 학교에서 사용하 는 지시적 표현이나 혹은 교과 어휘가 중요하며, 어휘의 양적인 증가뿐만 아니라 이미 습득한 어휘들의 깊이(폭)를 증가시킨다 고 한다(Jin et al., 2008). 동의어, 반의어, 상위어, 은유나 비유 와 같은 함축적 표현들을 이해하고 표현하게 되며, 어휘를 보

(c) This is an Open Access article distributed under the terms of the Creative Commons Attribution Non-Commercial License (https://creativecommons.org/licenses/by-nc/4.0) which permits unrestricted non-commercial use, distribution, and reproduction in any medium, provided the original work is properly cited.
다 정확하게 정의하고 필요한 상황에서 보다 쉽게 낱말 찾기 (word-finding)를 할 수 있게 된다(Kim, 2005; Pae et al., 2015). 어휘 능력은 학령기 아동들의 학업 성취를 위해 필수적 인 요소이며, 읽기 이해 능력을 예측할 수 있는 중요한 변인이다 (Cain \& Oackhill, 2007).

학령기 아동들의 어휘 수는 단어 의미를 수정하는 형태론 접두사와 접미사가 덧붙여지면서 증가하고 어휘 학습은 형태 론적 복합어를 포함해 다양하고 복잡해진다(Nagy \& Anderson, 1984). 따라서 조어 원리에 적용되는 한국어의 특성에 따라 한 단어가 몇 개의 형태소로 이루어져 있는지, 그 형태소가 단 어 내에서 어떤 역할을 하는지 아는 것은 한국어를 배우는 데 반드시 필요한 능력이다(Kim, 2014). 형태소 인식 능력은 의미 를 가진 최소 단위인 형태소에 대해 의식적으로 생각하고, 조작 하고, 형태소의 결합으로 이루어진 단어 형성의 규칙을 적용하 는 능력이다(Jung, 2014). 한국어의 단어는 단어 형성의 방법에 따라 단일어와 복합어로 나뉘며, 두 개 이상의 형태소로 이루 어지는 복합어는 어근과 어근이 결합된 합성어와 어근과 접사 가 결합된 파생어로 나누어진다. 형태소 인식 능력은 이러한 합 
성 및 파생의 방법으로 복합어를 구성하는 과정에서 형태소를 결합하고 분리할 수 있는 능력을 의미한다. 또한 용언의 어간에 다양한 어미가 결합하여 서술부의 세부적 의미를 더하는 굴절 어 형성 과정에서도 형태소를 인식하고 결합 및 분리하여 조작 할 수 있는 능력이 요구된다. 이러한 상위언어 인식 능력의 발달 은 학령기의 학업 능력에 많은 영향을 미친다(Kwon \& Seok, 2009). McBride-Chang et al.(2005)은 어휘지식에 음운 인식과 읽기 기술, 그리고 형태소 인식이 주된 영향을 미친다고 하였 다. 형태소 인식은 읽기에도 영향을 주기 때문에 학령기의 주요 한 의미 발달 과제이다(Apel et al., 2013). 최근에는 많은 연구 에서 형태소 인식 능력이 어휘력, 읽기 발달, 철자법과 관련됨 을 밝히고 있다. 국내의 의미 영역 상위언어 능력 연구에서 비 유 언어에 대한 연구가 14편으로 가장 많았으며 형태소 인식 능력에 대한 연구는 1편으로 상대적으로 적은 경향을 보였다 (Kim, 2014). 또한 형태소 인식이 어휘력 및 읽기에 미치는 영 향에 대한 중요성은 부각되었지만 음운 인식에 대한 연구에 비 해 형태소 인식에 대한 국내의 연구는 상대적으로 미비하다.

언어학습장애란 학습장애의 하위 유형으로 비언어 지능이 정상 범주에 있으나 구어의 기본과 읽기, 쓰기에 어려움을 가지 는 장애를 말한다(Kim \& Kang, 2005). 언어학습장애 아동은 구어 기초에 근본적인 약점이 있으며, 말이나 언어 발달이 지연 된 과거력이 있을 수 있다(Paul \& Norbury, 2012). Heo et al. (2011)의 연구에서 언어학습 부진 아동의 구어 특성을 살펴본 결과, 의미 영역과 문법 영역에서 어려움이 나타났다. 언어학습 장애 아동은 일반 아동보다 산출하는 어휘 수가 적고 어휘를 다양하게 사용하지 못하여, 학령기 때 두드러지게 발달하는 추 상어, 한자어, 유사어, 비유어 등의 이해 및 표현에 어려움을 가 진다(Lee, 2007). 이러한 언어 능력의 결함은 글의 내용을 이해 하는 데 영향을 미쳐 언어학습장애 아동은 읽기 이해에 제한 을 보인다(Bishop \& Adams, 1992). 언어학습에서 부진이 있을 경우, 심화된 교육 과정에 따라 학업을 성취하는 데 어려움이 초래될 뿐만 아니라 이후 성인기까지 지속적으로 부정적인 영 향이 미칠 수 있다(Yang \& Seo, 2009). Kim \& Jung(2015)의 연구에서는 학령기 일반 아동과 학습 부진 아동을 대상으로 형태소 인식 능력을 비교하였는데, 그 결과 학습 부진 아동들 이 일반 아동보다 형태소 인식 능력이 낮았다고 보고하였다.

학습장애 또는 언어학습장애 아동을 대상으로 한 국내의 어 휘 중재 연구를 살펴보면, Lee(2007)는 마인드맵을 이용해 언 어지도 프로그램을 실시하였고 학습장애 아동의 수용 및 표현 어휘력이 향상되었다고 하였다. Kang \& Lee(2011)는 그래픽 조직자 활용이 국어학습 부진아의 양적 및 질적 어휘력에서 긍 정적인 영향을 미쳤다고 하였다.

최근 외국 연구에서 학령기 아동의 언어 발달에 영향을 미치
는 요인으로서 형태소 인식에 관한 중요성이 논의되고 있다. Apel \& Diehm(2014)은 만 6 9세 아동들에게 형태지식 기반 중재를 실시한 결과, 통제 집단에 비해 중재를 받은 아동들의 형태소 인식 능력이 향상되었다고 하였다. 또한 중재를 받은 학 생들은 문해력이 크게 향상되었다. 언어장애로 진단받은 16 명 의 아동을 대상으로 실시한 Good et al.(2015)의 형태소 인식 능력 중재 연구 결과, 통제 집단에 비해 중재 대상 아동들은 철 자법과 어휘 능력에서 큰 향상을 보였다고 한다. 또한 대상 아 동들은 중재 내용을 일반화하여 단어를 파악할 수 있었다고 한다. Wolter \& Gibson(2015)은 형태소 인식 중재가 읽기장애 를 가진 학생의 언어 능력에 미치는 영향을 알아보고자 하였 다. 연구 결과, 형태소 인식 중재는 음운 인식, 어휘력, 읽기 이 해에 긍정적인 영향을 미쳤으며 읽기 정확도 또한 향상되었다 고 한다. $\operatorname{Jarad}(2015)$ 는 형태소 인식 중재는 학생들의 어휘에 긍정적인 영향을 미치며 특히 어휘 이해 능력과 긴밀한 관계가 있다고 하였다. 학생들은 학습을 위해 점차 길고, 추상적이며, 저빈도의 단어를 포함하는 복잡한 텍스트를 읽어야 한다. 이러 한 텍스트의 이해는 텍스트에 포함된 단어들이 친숙해지는 것 과 관련 있다(Northey, 2017). Nagy \& Anderson(1984)은 단어 와 형태소의 관계에 대해 아는 것은 빠른 어휘 성장과 관련 있 고, 그 결과 읽기 이해와 단어 읽기에서 긍정적인 효과를 이끌 어낼 수 있다고 하였다. 형태소 인식 능력은 다형태소 단어를 해석하고 판독하는 데 중요한 역할을 함으로써 모르는 단어에 대한 의미 유추를 가능하게 한다(Apel et al., 2013).

많은 연구자들이 형태소 인식이 학생들의 학업 능력에 상당 한 영향을 미친다는 것을 밝혀냈으나 학업에 어려움을 보이는 학생들에게 중재를 실시하는 연구는 그에 비해 적은 편이며 (Brimo, 2016) 특히 국내의 연구는 형태소 인식 능력과 아동들 의 읽기 능력에 초점을 맞추고 있으며 형태소 인식 능력과 어휘 력과의 관련성을 다룬 $\operatorname{Hong}(2002)$ 의 연구는 초등학교 6학년 일반 아동을 대상으로 하여, 언어 및 학습에 어려움을 겪는 아 동들의 형태소 인식 능력 중재 프로그램의 효과성을 살펴본 연 구는 거의 없는 실정이다. 이에 본 연구는 형태지식을 기반으로 한 중재 프로그램을 언어학습장애 아동에게 적용하여 양적, 질 적인 측면에서의 어휘 능력 향상에 미치는 효과에 대해 알아보 고자 하였다. 구체적인 연구 문제로는 형태소 인식 기반 어휘 중재 프로그램을 적용하였을 때, 이해 및 표현 어휘의 양적인 면에서 향상이 있는가? 또한 상의어, 유의어, 반의어, 비유어 및 단어 정의하기를 포함한 어휘의 질적인 향상 면에서 효과가 있 는가를 중심으로 고찰하고자 하였다. 


\section{CASE REPORT}

\section{연구 대상}

본 연구는 읽기에 어려움을 보이는 초등학생 3명(3학년 2명, 4 학년 1명)을 대상으로 하였다. 아동의 선정 기준은 다음과 같 다. 1) 수용·표현어휘력검사(Receptive \& Expressive Vocabulary Test, REVT) (Kim et al., 2009)에서 두 검사 모두 표준편 차(standard deviation, $\mathrm{SD}$ ) -1 미만이거나 수용 또는 표현어휘 력검사 결과 $-1 \mathrm{SD}$ 미만인 아동, 2) 한국어읽기검사(Korean Language-based Reading Assessment, KOLRA) (Pae et al., 2015)의 핵심검사 결과 표준점수 85점 이하인 아동, 3) 한국비 언어지능검사(Korean Comprehensive Test of Nonverbal Intelligence-Second Edition, K-CTONI-2) (Park, 2014) 결과 비 언어 지수 80 이상인 아동, 4) 학령기언어검사(Language Scale for School-aged Children, LSSC) (Lee et al., 2015)의 의미 언 어 지수 $-1 \mathrm{SD}$ 미만인 아동, 5) 읽기 문제가 시각, 청각, 정서행 동장애 등 다른 장애에 의한 것이 아닌 아동을 실험 연구의 대 상으로 선정하였다. 중재 전 대상 아동들의 어휘 능력을 알아 보기 위하여 평가를 실시하였다.

Table 1 은 개별 아동의 연령, 비언어 지능 지수, 수용·표현어 휘력검사 백분위 결과 및 학령기언어검사의 의미 언어 지수, 한 국어읽기검사의 읽기 언어 지수를 보여 준다. 대상자의 보호자 모두 연구 참여 전 연구의 목적 및 절차에 대한 설명을 듣고 연 구 참여 동의서에 서명을 하였다. 이 중 두 아동은 중재 기간 동안 읽기 및 어휘를 비롯한 어떤 언어 중재도 받지 않았고 아 동 1 의 경우 낱말 해독을 중심으로 한 읽기 교육을 받았으나 어휘를 비롯한 어떤 언어 중재도 받지 않은 아동이었다.

본 연구는 3 명의 학령기 언어학습장애 아동 사례를 중심으 로 형태지식 기반 어휘 중재 프로그램을 적용하여 사전-사후유지 단계에서 어휘 능력의 변화를 살펴보았다. 본 실험에 들어 가기 전 실험의 적절성을 평가하기 위해 초등 2, 3학년 일반 아 동 두 명을 대상으로 예비 실험을 실시하였다. 예비 실험에서 대 상 아동들은 프로그램 중 의미 단어에서보다 무의미 단어 만들 기 활동을 어려워하였으나 단어의 정의에 대해 치료사가 단서를 제공했을 때 수행이 가능하였다. 이에 본 실험에서는 아동들이
비단어 만들기를 어려워할 경우 연구자가 의미적인 단서를 제공 하는 것으로 예비 실험의 결과를 본 실험에 반영하였다.

\section{연구 도구}

대상자를 선정하기 위해 수용-표현어휘력검사(REVT), 한국 어읽기검사(KOLRA), 학령기언어검사(LSSC), 한국비언어지능 검사(K-CTONI-2)를 실시하였다. 또한 형태소인식능력평가 (Jung, 2014)와 다형태소단어정의하기평가를 실시하였다. 대상 자 선정 평가 도구 중에서 한국어읽기검사 및 한국비언어지능 검사를 제외하고 다른 검사 도구는 사후 평가, 유지 평가 기간 에도 대상 아동의 양적, 질적 어휘 능력을 평가하기 위해 반복 적용하였다.

형태소 인식 능력 측정을 위해 Jung(2014)의 과제를 수정하 여 의미/무의미 단어의 빈도를 늘리고 생성(예: 자동차의 '차와 같은 '차'가 들어가는 단어를 적어보세요.)과 유추 과제[예: 살 다: 살아서 :: 멀다: ( )]를 추가한 형태소인식능력평가를 실시 하였다. 총 문항 수는 84문항으로 형태소인식능력평가의 예는 Appendix 1에 제시하였다. 단어정의하기평가의 개발 과정은 중 재에 포함된 것과 아닌 것을 2 배수로 선정하여 언어치료학을 전공하는 대학원생 5 명을 대상으로 예비 검사를 실시하였다. 정의하기가 명료하지 않은 문항은 제외하고 최종 문항을 선정 하였으며 언어치료학 박사 학위 소지자 2명에게 타당도 검증을 받았다. 평가 단어 목록과 타당도 검증 결과 5점 척도로 하였 을 때 5 개의 문항에서 평균 4.8 점이었으며 타당도 검증 결과에 서 적절하지 않다고 평가된 1 개의 단어는 제외하였으며 확정된 총 29개 항목이었다.

\section{채점 방법}

중재가 끝난 후 언어학습장애 아동들의 수용-표현어휘력검 사와 학령기언어검사의 의미 전체 점수, 다형태소 단어 정의하 기 능력, 형태소 인식 능력을 측정하였다. 다형태소단어정의하 기평가는 목표 형태소의 의미를 정의에 포함하고 있으면 1점, 그렇지 않을 경우 0 점으로 채점하였다. 총 29문항으로 모두 정 반응하여 아동이 얻을 수 있는 총점은 29점이다. 형태소인식능 력평가는 정반응은 2점, 형태소를 사용하여 합성어, 파생어를

Table 1. Information of three subjects

\begin{tabular}{|c|c|c|c|c|c|c|c|c|c|}
\hline \multirow{2}{*}{$\mathrm{S}$} & \multirow{2}{*}{ Sex } & \multirow{2}{*}{ Age } & \multirow{2}{*}{$\begin{array}{l}\text { Nonverbal } \\
\text { intelligence }\end{array}$} & \multicolumn{2}{|c|}{ REVT (\%ile) } & \multicolumn{2}{|c|}{ LSSC-SQ } & \multicolumn{2}{|c|}{ KOLRA-RLQ } \\
\hline & & & & REVT-R & REVT-E & SS & \%ile & SS & \%ile \\
\hline S1 & $\mathrm{M}$ & $9 ; 1$ & 91 & 10 & $<10$ & 29 & 4.8 & 81 & 11 \\
\hline S2 & $\mathrm{M}$ & $8 ; 6$ & 83 & $<10$ & $<10$ & 20 & 0.8 & 70 & 2 \\
\hline S3 & $\mathrm{M}$ & $9 ; 4$ & 119 & $40-50$ & $<10$ & 36 & 12.9 & 77 & 6 \\
\hline
\end{tabular}

S: suject, M: male, REVT: Receptive \& Expressive Vocabulary Test, LSSC-SQ: Language Scale for School-aged Children-Semantic Quotient, KOLRA-RLQ: Korean Language based Reading Assessment-Reading Language Quotient, SS: standard score 
만들 수는 있으나 맞춤법에 오류가 있을 경우 1점(예: 뒷문-뒤 문, 바늘질-바느질 등), 그렇지 않은 경우에는 0점으로 채점하 였다. 아동이 쓰기를 거부해 평가 문항에 반응하지 않은 경우 에는 0 점으로 채점하였다. 총 문항 수 84문항을 모두 정반응하 였을 때 아동이 얻을 수 있는 총점은 168점이다.

\section{형태지식 기반 어휘 중재 프로그램의 구성}

본 연구에 사용된 형태지식 기반 언어 중재 프로그램 절차는 선행 연구(Apel et al., 2013; Brimo, 2016)를 기반으로 연구자 가 직접 제작하였다. 프로그램 절차와 내용은 언어치료학 박사 학위 소지자 2명에게 타당도 검증을 받았다. 타당도 검증 결과 5 점 척도로 하였을 때 5 개의 문항에서 평균 5 점이었다.

중재에 사용되는 단어는 초등학교 $1,2,3$ 학년 국어 교과서에 서 고빈도로 나타나는 단어로 선정하였으며, $\operatorname{Kim}(2003)$ 의 '등 급별 국어교육용 어휘'에서 1,2 등급 단어를 선정하였다. 선정 된 목록은 Table 2 와 같다. 중재 단어는 언어치료학 박사 학위 소지자 2명에게 타당도 검증을 받았다. 타당도 검증 결과 5점 척도로 하였을 때 5 개의 문항에서 평균 5 점이었으며 타당도 검 증결과 부적절한 단어는 제외하였으며 확정된 단어는 합성 어 9 개, 접두사 6 개, 접미사 14 개로 총 29 개이다. 중재 단어는 Table 2에 제시하였다.

중재는 일주일에 2회 총 9주간 40분씩 총 18회기 실시하였 다. 한 회기당 합성어는 3 개, 접두사와 접미사는 2 개를 목표로 하였다. 각 목표별 중재 절차는 총 5 단계로 구성하였으며, 각 단 계별 구체적인 중재 프로그램 내용은 다음과 같다.

1 단계는 듣기 활동으로 약 5 분 동안 목표 어휘를 소개하고 목표 형태소를 듣는 활동을 실시하였다. 단어나 문장을 들려주 고 목표 형태소를 포함한 경우 종을 치거나 손을 들도록 하였 다. 이때 목표 형태소를 포함한 것과 포함하지 않은 단어를 함 께 사용하였다. 들려준 단어는 목표 형태소가 없는 어근 단어 만 들려주거나 단어의 소리가 유사한 단어를 사용했다. 한 회기 에 6개의 단어를 사용했으며 단어를 먼저 들려준 뒤 문장 듣기 활동을 진행했다. 듣기 활동에 사용한 문장은 4 5어절 수준으 로 통제하였다.

2 단계에서는 단어카드를 이용해 약 5 분 동안 1 단계에서 활동 한 단어를 분류하였다. 목표 형태소가 있는지 없는지 말하고
서로 다른 바구니에 분류하였다. 목표 형태소가 없는 단어를 정의하고 목표 형태소가 있을 경우에 의미가 달라지는 것을 확인하였다. 분류한 단어들의 차이에 대해 설명하고 목표 형태 소가 포함된 단어들을 정의하였다. 목표 형태소가 포함된 경 우, 단어의 뜻에 동일한 내용이 포함되는 것을 확인하였다. 아 동이 활동에 사용되는 단어를 처음 들어보거나 의미를 알지 못한다고 했을 때는 치료사가 그림카드와 함께 단어의 의미를 알려주었다.

3 단계는 형태소 합성과 분리하기 단계이다. 약 20 분 동안 스 프링과 같이 시각적으로 분리와 합성의 원리를 보여줄 수 있는 사물을 활용하거나 색종이를 자르며 형태소 분리와 합성을 직 접 실시하였다. 합성어의 경우 형태소를 분리해도 혼자 쓸 수 있는 단어가 두 개라는 것을 강조하였다. 파생어는 형태소를 분 리하면 접두사 또는 접미사는 혼자 쓸 수 없다는 것을 강조하 였다. 형태소를 분리한 상태에서 분리한 형태소의 의미에 대해 설명하고 합성했을 때는 어떤 의미가 되는지 설명하였다. 다음 으로 목표 형태소를 사용하여 의미 단어와 비단어를 만들어보 았다. 이때 마인드맵이나 표를 이용하였다. 아동이 단어를 만들 기 힘들어할 때는 치료사가 의미 단서를 제공하였다.

4단계는 맥락에서 목표 단어 의미 이해 전략을 사용하는 단 계이다. 약 5 분 동안 중재 훈련 단어가 포함된 문장을 들려주고 의미를 이해하는 활동을 실시하였다. 들려주는 문장은 6 어절 을 넘지 않도록 통제하였다. 문장을 들려주고 아동이 문장의 의미에 대해 설명하도록 한다. 아동이 문장의 의미 파악을 어려 워할 때는 치료사가 먼저 질문하였다(예: '요리사가 되어서 엄 마를 기쁘게 해줘요.-엄마를 어떻게 기쁘게 해줄까?). 아동이 적절하게 문장의 의미를 파악했을 때는 문장에서 어떤 단어를 단서로 파악했는지 질문한다. 이때 배운 목표 형태소를 사용해 내용을 어떻게 이해하게 되었는지 토의하였다.

마지막 5단계에서는 회기에서 사용한 단어와 만든 단어로 단어 사전을 만들었다. 사전의 가장 위에는 목표 형태소를 적 고 색깔을 다르게 하여 강조 표시를 하였다. 접두사와 접미사 는 접사의 의미를 사전에 적도록 하였다. 다음으로 아동이 직 접 목표 단어를 사용해 문장을 만들어보았다. 치료사가 먼저 아동이 만든 단어 중 하나를 골라 문장을 만들어 모델을 제공 하였다. 아동에게 먼저 구어로 문장을 만들도록 지시하였다.

Table 2. Intervention words list

\begin{tabular}{lrl}
\hline \multicolumn{1}{c}{ Type } & $\mathrm{n}$ & Target morpheme \\
\hline $\begin{array}{l}\text { Compound } \\
\text { Derivative }\end{array}$ & 9 & honey (꿀), eye (눈), water (물), paper (종이), cotton (솜), bird (새), leaf (잎), sound (소리), stone (돌) \\
$\begin{array}{l}\text { Prefix } \\
\text { Suffix }\end{array}$ & 6 & $\begin{array}{l}\text { man- (맨-), han- (한-), doi- (되-), hat- (햇-), heot- (헛-), mi- (미-) } \\
\text {-sa (-사), -gi (-기), -ja (-자), -jang (-장), -kkureogi (-꾸러기), -wha (-화), -jangee (-쟁이), -ssi (-씨), -bo (-보), } \\
\text {-gam (-감), -dapta (-답다), -gae (-개), passive affix, causativeverb affix }\end{array}$ \\
\hline
\end{tabular}


아동의 문장에 목표 형태소가 포함된 단어가 있는지 확인하고 적을 수 있도록 하였다. 이때 아동이 만든 문장의 길이가 3어절 이하인 경우 치료사가 언어적 촉진을 하였다. 또한 아동이 적은 문장의 맞춤법에 오류가 있을 경우 문장을 읽고 오류가 있는지 찾도록 하였고 스스로 찾지 못하는 경우 치료사가 맞춤법을 수 정해주었다. 아동이 직접 만든 단어의 정의를 적는 것은 과제 로 해오도록 하였다. 이 중재 프로그램을 적용한 회기 구성의 예는 Appendix 2에 제시하였다.

\section{연구 절차}

실험은 사전 평가-중재-사후 평가-유지 단계로 구성하였다. 사전 평가에서는 수용·표현어휘력검사, 학령기언어검사, 형태 소인식능력평가, 다형태소정의하기평가를 실시하였다. 중재 단 계는 주당 2회기로 9주간 프로그램을 실시하였고, Table 2에 제시한 중재 단어를 중심으로 합성어 3회기, 파생접미사 7회기, 파생접두사 3회기 중재하였다. 또한 선행 연구(Apel et al., 2013; Brimo, 2016)를 기반으로 4, 9, 13, 18회기에는 리뷰 단계 를 가졌다. PPT를 이용하여 목표 단어들을 정의하도록 하였다. 회기에서 사용한 단어들을 분리하고 합성하는 활동을 실시하 였다. 회기에서 사용한 단어들의 어근이나 접사와 소리는 같지 만 뜻은 다른 단어가 있다면 그 단어를 활용하여 단어 만들기 를 해보았다. 보드게임을 활용하여 아동과 목표 어근, 접사를 포함하는 단어 만들기 활동을 하였다. 리뷰 단계가 끝날 때 다 시 한 번 목표 단어를 아동이 정의하도록 하였다.

중재가 끝난 후 대상자의 어휘 능력을 평가하기 위해 사전 평가에서 실시한 수용·표현어휘력검사(REVT), 학령기언어검 사(LSSC)와 형태소인식능력평가 및 다형태소단어정의하기평 가를 실시하였다. 중재 종료부터 2주 후 사후 평가에서 실시한 검사를 동일하게 실시하여 중재 후 향상된 어휘 능력이 일정
시간이 지난 후에도 유지되고 있는지 알아보았다.

\section{연구 결과}

수용어휘력검사(REVT-R) 결과

수용어휘력검사 결과, 세 아동 모두 중재 이후 수용어휘력 원점수가 증가하였다. S1과 2는 중재 이후 원점수가 15 점 이상 증가하였으며 수용어휘력검사의 백분위도 증가하였다. S3의 경 우 지속적으로 수용어휘력 점수가 증가하는 경향을 보였다. 수 용어휘력검사의 결과는 Table 3과 Figure 1에 제시하였다.

$\mathrm{S} 1$ 은 사전 평가 수용어휘력검사 원점수 79 점, 백분위 $10 \%$ ile 미만으로 나타났고 사후 평가는 원점수 94점, 백분위 $10 \%$ ile 로 나타났다. 중재 후 원점수가 15점 증가하였고 백분위도 변 화하였다. 유지 평가에서도 사후 평가와 동일한 원점수와 백분 위로 나타나 중재를 통해 학습된 능력이 유지되고 있는 것으로 나타났다. S2는 사전 평가 수용어휘력검사 원점수 69점, 백분위 $10 \%$ ile 미만으로 나타났고 사후 평가는 원점수 88점, 백분위 30 40\%ile로 나타났다. 중재 후 원점수가 20점 증가하였고 백 분위에서도 증가된 모습을 보였다. 유지 평가에서는 원점수 82 점, 백분위 10 20\%ile로 나타나 사후 평가의 점수보다는 다소 낮게 나타났으나 이는 사전 평가의 원점수보다는 높아 중재를 통해 학습된 능력이 유지되고 있는 것으로 나타났다. S3은 사

Table 3. REVT-R results of three subjects

\begin{tabular}{ccccccccc}
\hline \multirow{2}{*}{ S } & \multicolumn{2}{c}{ Pre-test } & & \multicolumn{2}{c}{ Post-test } & & \multicolumn{2}{c}{ Maintenance-test } \\
\cline { 2 - 3 } & Score & \%ile & & Score & \%ile & & Score & \%ile \\
\hline S1 & 79 & $<10$ & & 94 & 10 & & 94 & 10 \\
S2 & 69 & $<10$ & & 88 & $30-40$ & & 82 & $10-20$ \\
S3 & 105 & $40-50$ & & 109 & $40-50$ & & 111 & 50 \\
\hline
\end{tabular}

S: subject, REVT: Receptive \& Expressive Vocabulary Test
Figure 1. REVT-R results of three subjects. REVT: Receptive \& Expressive Vocabulary Test.

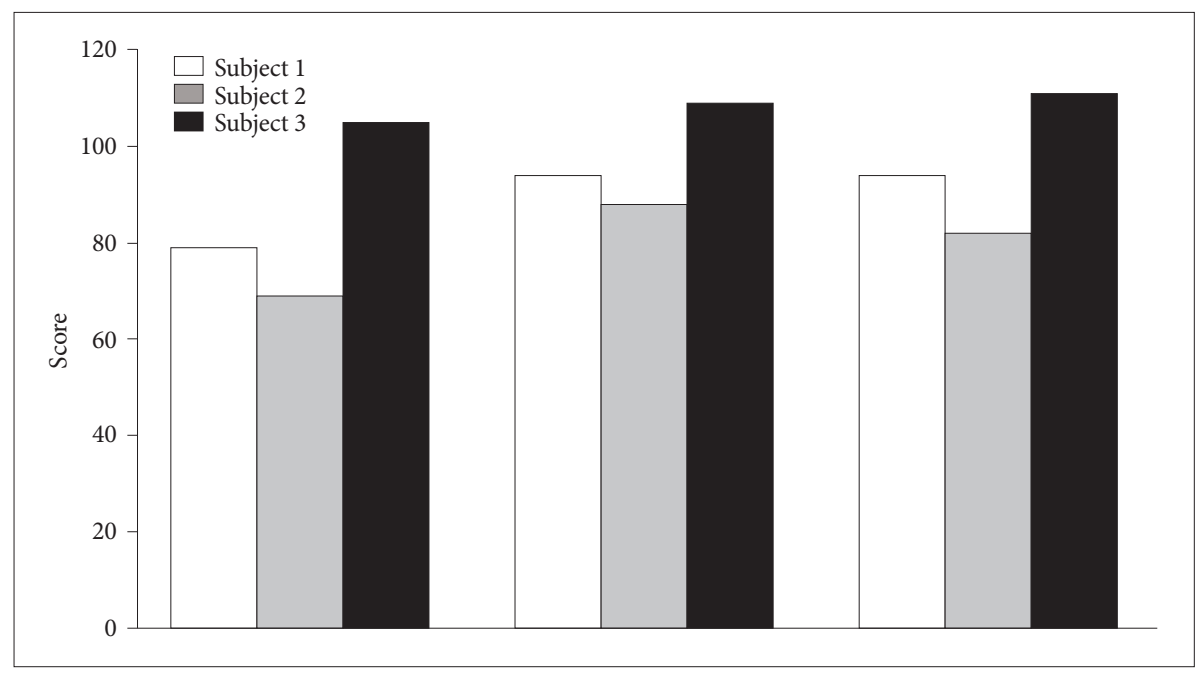


전 평가 수용어휘력검사 원점수 105 , 백분위 40 50\%ile로 나 타났으며 사후 평가는 원점수 109, 백분위 40 50\%ile로 나타 났다. 중재 이후 원점수가 4점 증가하였다. 유지 평가에서는 원 점수 111점, 백분위 50\%ile로 사전 평가에 비해 중재 이후 사후 와 유지 평가에서 지속적인 증가 경향을 보였다.

\section{표현어휘력검사(REVT-E) 결과}

표현어휘력검사 결과, 대상 아동 모두 사전 평가와 비교해 중 재 이후 실시된 사후와 유지 평가에서 높은 원점수를 나타냈다. 대상 아동들의 표현어휘력검사의 결과는 Table 4와 Figure 2에 제시하였다.

$\mathrm{S} 1$ 은 사전 평가 표현어휘력검사 원점수 68점, 백분위 $10 \%$ ile 미만으로 나타났고 사후 평가는 원점수 90점, 백분위 $10 \%$ ile 미만으로나타났다. 중재 후 원점수가 23점 증가하였다. 유지 평 가에서는 원점수 93점, 백분위 10\%ile 미만으로 나타나 또래보다 는 낮은 수행력을 보였으나 사전 평가보다 원점수는 25점, 사후 평 가보다 3점이 증가하여 큰 차이를 보였다고 할 수 있다. S1은 중재 이후 사후와 유지 평가에서 꾸준히 어휘가 향상되는 경향을 보였 다. S2는 사전 평가 표현어휘력검사 원점수 71 , 백분위 10\%ile 미만 으로 나타났다. 사후 평가는 원점수 78 , 백분위 $10 \%$ ile로 나타나 사전 평가에 비해 원점수가 7점 증가하였다. 유지 평가에서는 원 점수 79, 백분위 10 20\%ile로 나타나 중재를 통해 학습된 능력이 지속되고 있으며 어휘가 지속적으로 향상되고 있는 경향성을 보

Table 4. REVT-E results of three subjects

\begin{tabular}{ccccccccc}
\hline \multirow{2}{*}{ S } & \multicolumn{2}{c}{ Pre-test } & & \multicolumn{2}{c}{ Post-test } & & \multicolumn{2}{c}{ Maintenance-test } \\
\cline { 2 - 3 } & Score & \%ile & & Score & \%ile & & Score & \%ile \\
\hline S1 & 68 & $<10$ & & 90 & $<10$ & & 93 & $<10$ \\
S2 & 71 & $<10$ & & 78 & 10 & & 79 & $10-20$ \\
S3 & 77 & $<10$ & & 98 & $10-20$ & & 98 & $10-20$ \\
\hline
\end{tabular}

S: subject, REVT: Receptive \& Expressive Vocabulary Test
였다. S3은 사전 평가 표현어휘력검사 원점수 77 , 백분위 $10 \%$ ile 미만으로 나타났다. 사후 평가는 사전 평가의 원점수보다 21점 증가하여 원점수 98점, 백분위 10 20\%ile로 나타나 백분위에서 도 변화가 나타났다. 유지 평가에서도 사후 평가와 동일한 원점 수와 백분위로 중재를 통해 학습된 능력이 지속되었다.

\section{학령기언어검사(LSSC) 결과}

학령기언어검사 결과, 대상 아동들의 의미 전체 환산 점수와 백분위는 중재 이후 증가하였다. 대상 아동들의 환산 점수는 12점 이상 증가하였고 유지 과정에서도 지속적으로 향상되고 있는 경향이 나타났다. 대상 아동들의 학령기언어검사 결과는 Table 5와 Figure 3에 제시하였다.

$\mathrm{S} 1$ 은 학령기언어검사 결과 사전 평가 의미 전체 환산 점수 29점, 백분위 4.8\%ile로 나타났다. 중재 후 사후 평가에서 환산 점수 40점, 백분위 21.2\%ile로 나타났다. 중재 전보다 환산 점수가 11점 증가하였고 백분위는 약 16\%ile 높게 나타났다. 유지 평가 에서는 환산 점수 44점, 백분위 $32.0 \%$ ile로 중재 후에 사전 평 가보다 높은 수행력을 보였으며 유지 평가에서도 유지되고 있 는 것으로 나타났다. S2는 학령기언어검사 결과 사전 평가 의미 전체 환산 점수 20점, 백분위 $0.8 \%$ ile로 나타났다. 중재 후 사 후 평가에서 환산 점수 34점, 백분위 10.3\%ile로 나타났다. 중재 전보다 환산 점수가 14점 증가하였고 백분위는 약 9\%ile 높게

Table 5. Language Scale for School-aged Children results of three subjects

\begin{tabular}{ccccccccc}
\hline \multirow{2}{*}{ S } & \multicolumn{2}{c}{ Pre-test } & & \multicolumn{2}{c}{ Post-test } & & \multicolumn{2}{c}{ Maintenance-test } \\
\cline { 2 - 3 } & Score & \%ile & & Score & \%ile & & Score & \%ile \\
\hline S1 & 29 & 4.8 & & 40 & 21.2 & & 44 & 32.0 \\
S2 & 20 & 0.8 & & 34 & 10.3 & & 35 & 11.5 \\
S3 & 36 & 12.9 & & 46 & 39.5 & & 48 & 44.7 \\
\hline
\end{tabular}

S: subject

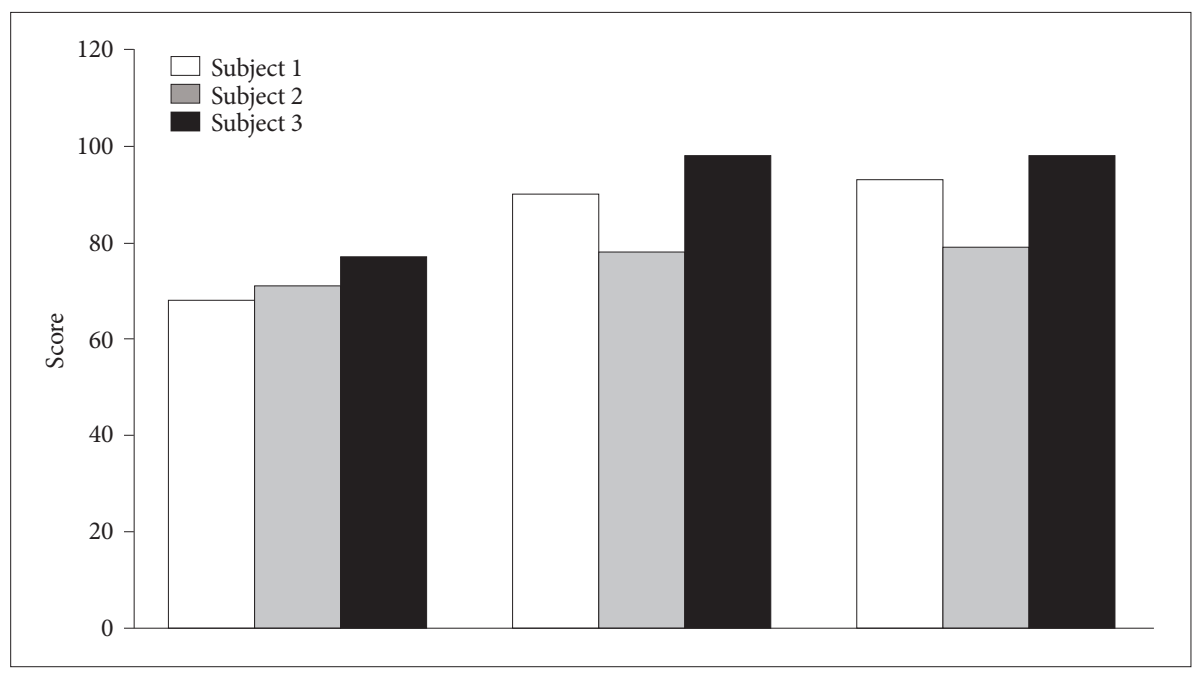

Figure 2. REVT-E results of three subjects. REVT: Receptive \& Expressive Vocabulary Test. 
Figure 3. Language Scale for Schoolaged Children results of three subjects.

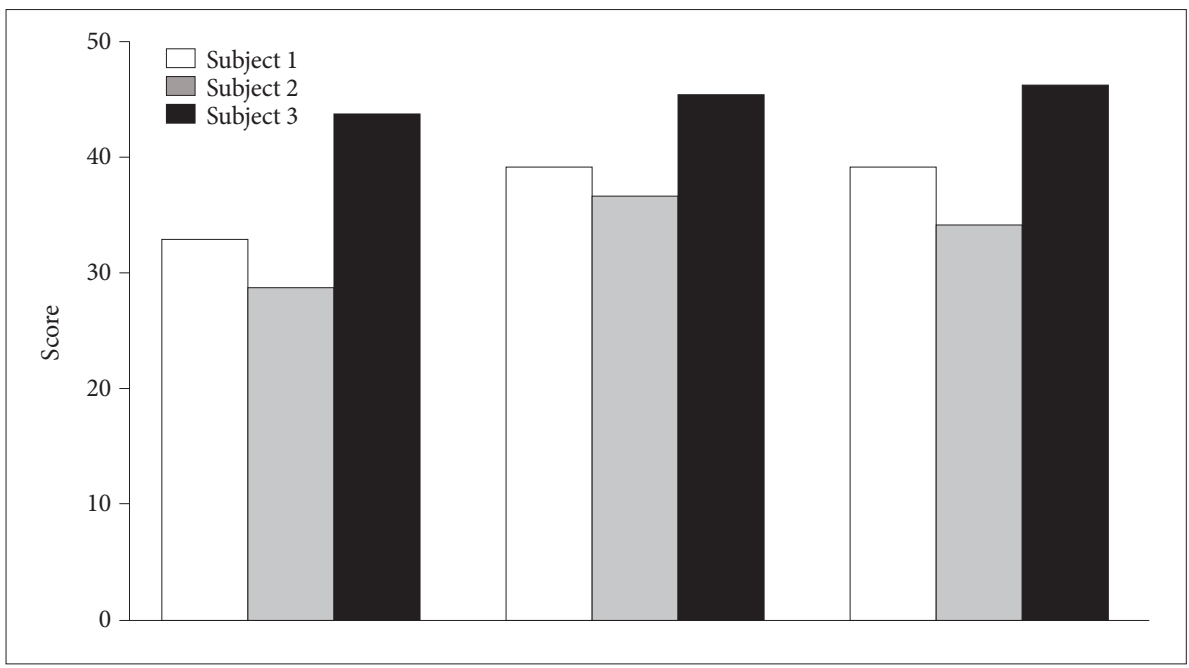

나타났다. 유지 평가에서는 환산 점수 35점, 백분위 $11.5 \%$ ile로 중재 후에 사전 평가보다 높은 수행력을 보였으며 유지 평가에서 도 유지되고 있는 것으로 나타났다. S3은 학령기언어검사 결과 사전 평가 의미 전체 환산 점수 36 점, 백분위 $12.9 \%$ ile로 나타났 다. 중재 후 사후 평가에서 환산 점수 46점, 백분위 39.5\%ile로 나타났다. 중재 전보다 환산 점수가 10점 증가하였고 백분위는 약 26\%ile 높게 나타났다. 유지 평가에서는 환산 점수 48점, 백 분위 $44.7 \%$ ile로 중재 후에 사전 평가보다 높은 수행력을 보였 으며 유지 평가에서도 유지되고 있는 것으로 나타났다.

\section{다형태소단어정의하기평가 결과}

다형태소단어정의하기평가 결과, 대상 아동들은 중재 후 사 후와 유지 평가에서 사전 평가보다 높은 점수를 나타냈다. 중 재 전 아동들의 수준은 세 아동 모두 10점 미만이었고 개인의 차이는 있었으나 중재 후 대상 아동들은 10점 이상이 향상되었 다. 대상 아동들의 다형태소단어정의하기평가 결과는 Table 6 과 Figure 4에 제시하였다.

$\mathrm{S} 1$ 은 다형태소단어정의하기 사전 평가 결과 원점수 7점으로 나타났다. 사후 평가에서는 점수가 11점 증가하여 18점으로 나 타났다. 유지 평가에서 20점으로 중재를 통해 학습된 능력이 지속되고 있으며 향상되는 경향이 나타났다. 훈련 단어로 사용 된 단어 중 합성어 '강물, 유리컵, 숨소리, 물새', 파생어 ‘되찾다, 맨손, 미공개, 울리다, 도시화, 심술꾸러기, 사진기'를 S1은 사후 평가에서 정반응하였다. 중재 후 아동의 정의하기 형태는 형태 소 단위의 의미를 유추하는 전략을 사용하여 훈련 단어로 사 용되지 않았지만 합성어 '생일잔치, 가루약, 달빛'과 파생어 '새 하얗다를 정반응할 수 있었다.

$\mathrm{S} 2$ 는 다형태소단어정의하기 사전 평가 결과 원점수 0점으로 나타났다. 사후 평가 결과 15점으로 중재 후에 높은 수행력을
Table 6. Multimorphemic words definition test results of three subjects

\begin{tabular}{cccc}
\hline & Pre-test & Post-test & Maintenance-test \\
\hline S1 & 7 & 18 & 20 \\
S2 & 0 & 15 & 15 \\
S3 & 9 & 27 & 23 \\
\hline
\end{tabular}

S: subject

보였다. 유지 평가에서도 동일한 원점수로 중재를 통해 학습된 능력이 지속되고 있는 것으로 나타났다. 아동은 사후와 유지 평가 시 평가에 사용되는 단어들이 한 개의 단어지만 분리를 할 수 있다는 것을 치료사에게 설명하며 정의를 하였다. 훈련 단어로 사용한 단어 중 중재 후 정반응한 문항은 합성어 '유리 컵, 숨소리, 물새, 꽃길이었고 파생어 '되찾다, 맨손, 미공개, 도 시화, 심술꾸러기, 꾀보, 사진기, 지우개'였다. 훈련 단어로 사용 되지 않았지만 $\mathrm{S} 2$ 가 사후 평가 또는 유지 평가에서 정반응한 문항은 합성어 '가루약, 물새'와 파생어 '새하얗다, 무용가, 부채 질, 사냥꾼'이었다.

$\mathrm{S} 3$ 은 다형태소단어정의하기 사전 평가 결과 원점수 9점으로 나타났다. 사후 평가에서 27점으로 나타났다. 유지 평가에서 23점으로 중재 후에 높은 수행력을 보였으며 유지 평가에서도 유지되고 있는 것으로 나타났다. S3이 사전 평가에서 오반응했 으나 사후와 유지 평가 모두에서 정반응한 문항은 합성어 '강 물, 꽃길, 유리컵, 가루약, 물새, 달빛'과 파생어 '되찾다, 미공개, 새하얗다, 도시화, 책임감, 심술꾸러기, 꾀보, 사진기, 지우개, 무 용가, 부채질'이었다. 중재 후 아동의 정의하기 형태는 평가 단어 들이 복합어라는 것을 이해하여 정의하는 형태로 변화하였다. 사후 평가에서 아동은 ‘풋사과'를 정의할 때 '풋이랑 사과가 만 났으니까 풋 하고 웃는 사과하고 형태소 단위의 의미를 유추하 는 전략을 사용하는 모습이 관찰되었다. 훈련 단어로 사용한 


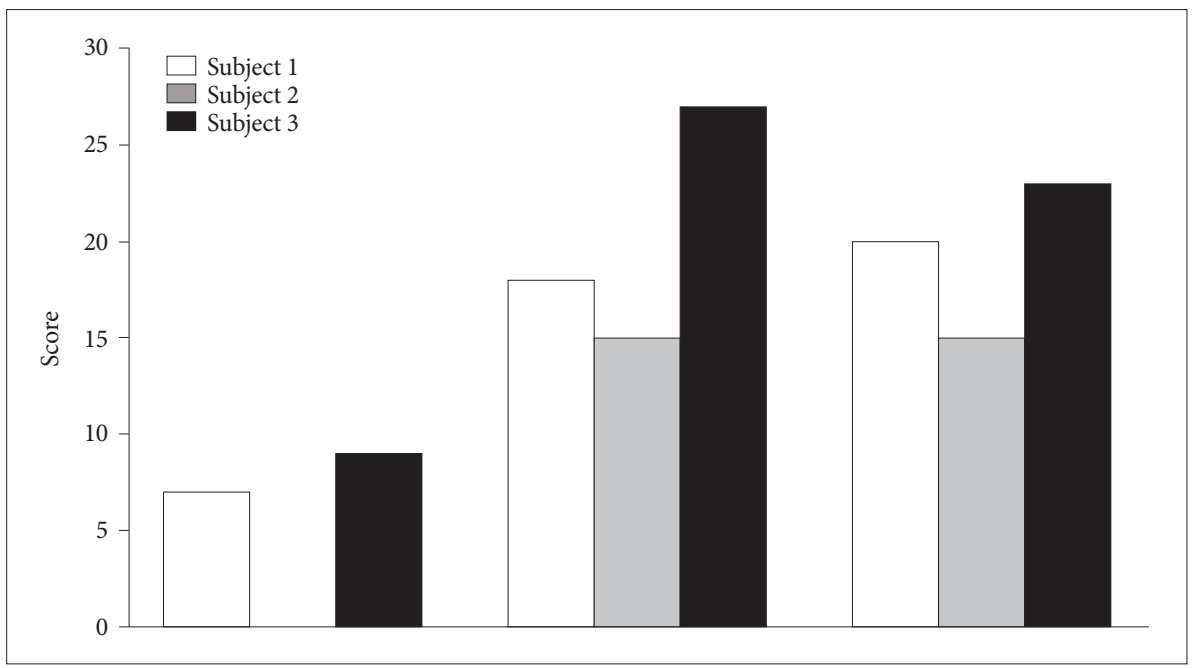

Figure 4. Multimorphemic words definition test results of three subjects.

단어 중 S3이 중재 후 정반응한 문항은 합성어 '강물, 꽃길, 유 리컵, 물새'였고 파생어 '되찾다, 미공개, 울리다, 도시화, 책임감, 심술꾸러기, 꾀보, 사진기, 지우개'였다. 훈련 단어로 사용되지 않았지만 S3이 사후 평가 또는 유지 평가에서 정반응한 문항은 합성어 '가루약, 물새, 달빛'과 파생어 '새하얗다, 무용가, 부채질' 이었다.

\section{형태소인식능력평가 결과}

형태소인식능력평가 결과, 대상 아동들은 모두 사전 평가에 비해 중재 후 실시된 사후와 유지 평가에서 높은 점수를 나타 냈다. 대상 아동들의 형태소인식능력평가의 결과는 Table 7과 Figure 5에 제시하였다.

형태소인식능력평가 결과 $\mathrm{S} 1$ 은 사전 평가 원점수 75 점, 사후 평가 원점수 100점, 유지 평가 102점으로 나타났다. 중재 이후 에 사후 평가에서는 25 점이, 2 주 후 실시한 유지 평가에서는 그 보다 2점이 더 증가하여 중재를 통해 학습된 능력이 지속되고 있는 것으로 나타났다. S1은 사전 평가 시 검사를 거부하는 모 습을 보였고 평가자에게 대신 적어달라고 부탁하였다. S1은 합 성 과제, 파생 과제, 유추 과제, 산출 과제에서 사전 평가에 비 해 높은 점수로 나타났다. 또한 의미 단어와 무의미 단어 총점 또한 사후 및 유지 평가에서 높게 나타났다. S1이 사전 평가보 다 높은 점수를 받은 문항 유형은 의미 단어 합성유추(빨간:빨 간꽃 :: 파란:파란꽃), 무의미 단어 합성유추(연필:연필꽃이 :: 자:자꼿이), 의미 단어 파생유추(음악:음악가 :: 소설:소설가), 무의미 단어 파생유추(장난:장난꾸러기 :: 눈치:눈치꾸러기), 생 성(물병의 ‘병'과 같은 뜻을 가진 '병’이 들어있는 단어), 의미 단 어 굴절산출[아프다: 배가 ( ) 병원에 갔다.]이었다. 중재 후 $\mathrm{S} 1$ 이 가장 큰 향상을 보인 부분은 생성 과제와 유추 과제였으며 각각 중재 전에 비해 사후 평가에서 12점씩 증가하였다. 2주 후 유지
Table 7. Morphological awareness test results of three subjects

\begin{tabular}{rccc}
\hline & Pre-test & Post-test & Maintenance-test \\
\hline S1 & 75 & 100 & 102 \\
S2 & 60 & 83 & 89 \\
S3 & 104 & 111 & 105 \\
\hline
\end{tabular}

S: subject

평가에서도 중재를 통해 학습된 능력이 지속되며 계속해 향상 되는 경향을 보여 생성 과제는 사후 평가보다 1점이 증가하여 13점, 유추 과제는 2점이 증가하여 14점으로 나타났다. S1은 사 후 평가 중 '나는 동네 제일 가는 ( )이다.라는 문항에서 참고 낱 말인 “멋을 보고 “멋쟁이도 되지만 멋꾸러기도 될 수 있어요.”라 고 말하며 중재에서 배운 접미사를 사용해 비단어를 만드는 모 습이 관찰되었다.

$\mathrm{S} 2$ 는 형태소인식능력 사전 평가 원점수 60점, 사후 평가 원 점수 83점, 유지 평가 89점으로 나타났다. 중재 이후에 사후 평 가에서는 23점이, 2주 후 실시한 유지 평가에서는 그보다 6점이 더 증가하여 중재를 통해 학습된 능력이 지속되고 있는 것으로 나타났다. $\mathrm{S} 2$ 는 합성 과제, 파생 과제, 굴절 과제, 유추 과제, 산 출 과제에서 사전 평가보다 높은 점수로 나타났다. 또한 의미 단어와 무의미 단어 총점도 사전 평가에 비해 높은 점수였다. $\mathrm{S} 2$ 가 사전 평가보다 높은 점수를 받은 문항 유형은 의미 단어 합성유추, 무의미 단어 합성산출, 의미 단어 파생유추, 무의미 단어 파생유추, 의미 단어 파생산출['일' 집을 지으려면 ( )이 많이 필요하다], 의미 단어 굴절산출, 무의미 단어 굴절산출[얼 피다: 이 물건에 ( ) 것을 빼라]이었다. 중재 후 S2가 가장 큰 향상을 보인 부분은 굴절 과제와 산출 과제였으며 각각 중재 전에 비해 사후 평가에서 10점, 14점씩 증가하였다. 2주 후 유 지 평가에서도 중재를 통해 학습된 능력이 지속되며 계속해 향 상되는 경향을 보여 굴절 과제는 사후 평가보다 4점이 증가하 


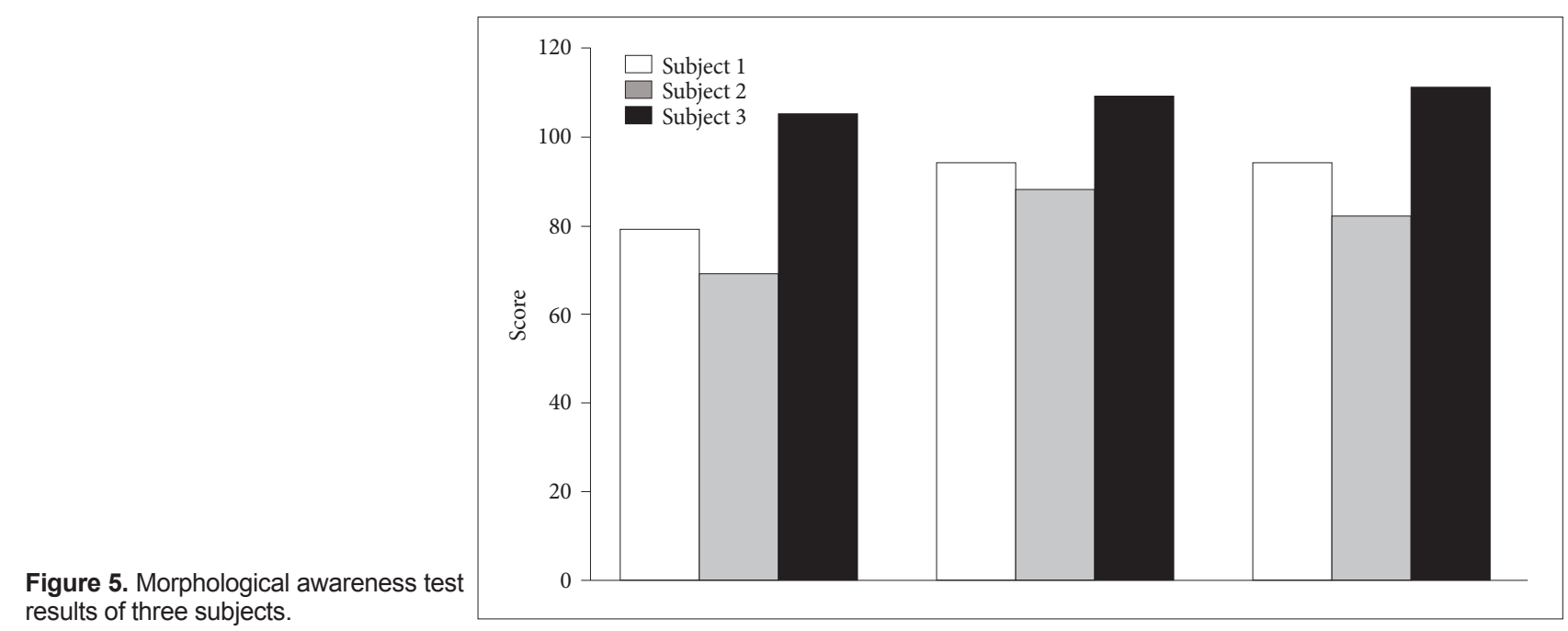

여 14점, 산출 과제는 6점이 증가하여 20점으로 나타났다. S2 는 굴절산출 의미 과제를 사전 평가에서 실시할 때 단어를 원 형 그대로 적었다(예: 솔로몬은 슬기롭다 사람이다, 친구들과 사이좋다 놀아야 한다, 등). 그러나 사후와 유지 평가에서는 적 절한 형태를 갖추어 단어를 산출할 수 있었다.

형태소인식능력평가 결과 S3은 사전 평가 원점수 104점, 사 후 평가 원점수 111점, 유지 평가 105점으로 나타났다. 중재 이 후에 사후 평가에서는 7점이 증가하였다. 유지 평가에서는 사 후 평가보다 다소 낮은 점수를 보였으나 사전 평가보다는 조금 높은 점수로 나타나 중재를 통해 학습된 능력이 지속되고 있는 것으로 나타났다. S3은 형태소인식능력평가 자체를 거부하는 모습을 보였다. 쓰기 과제에서 자신감이 적어 쓰지 않고 말로 대답하고 싶다고 설명하였다. S3은 파생 과제, 생성 과제, 굴절 과제, 산출 과제에서 사전 평가에 비해 사후 평가 및 유지 평가 에서 높은 점수로 나타났다. 또한 의미 단어와 무의미 단어 총 점도 사전 평가에 비해 높게 나타났다. S3이 사전 평가보다 높 은 점수를 받은 문항 유형은 생성, 의미 단어 굴절산출, 무의미 단어 굴절산출이었다. 중재 후 S3이 가장 큰 향상을 보인 부분 은 굴절 과제와 산출 과제였으며 각각 중재 전에 비해 사후 평 가에서 3점, 6점씩 증가하였다. 2주 후 유지 평가에서 굴절 과 제는 사후 평가보다 1점이 증가하여 4점, 산출 과제는 사후 평 가의 점수보다는 2점 낮은 4점으로 나타났으나 중재를 통해 학 습된 능력이 지속되고 있는 것으로 나타났다. S3은 사전 평가 시 형태소인식능력평가 전체를 거부하는 모습을 보였다. 쓰기 에 자신 없는 태도를 보이며 평가자에게 대신 답안을 작성해달 라고 부탁하는 모습이 관찰되었다. 그러나 사후와 유지 평가에 서는 스스로 끝까지 답을 적을 수 있었다.

\section{DISCUSSIONS}

본 연구는 형태지식 기반 어휘 중재가 언어학습장애 아동의 어휘에 미치는 효과를 알아보고자 하였다. 아동들의 양적, 질 적 어휘 능력을 알아보기 위해 수용·표현어휘력검사와 학령기 언어검사를 사용하였고 아동들의 형태소 인식 능력과 다형태 소 단어 정의하기 능력을 평가하기 위해 비공식 평가를 사용했 으며 연구의 논의는 다음과 같다.

첫째, 중재 후 대상 아동의 수용-표현어휘력검사의 원점수가 증가하였다. 이를 통해 중재 후 어휘의 양적 능력이 향상되었음 을 알 수 있다. Ramirez et al.(2014)은 서로 다른 언어 능력을 가진 아동들의 어휘력과 형태소 인식 능력을 측정하였다. 연구 결과, 어휘력과 형태소 인식 능력은 정적인 상관관계가 있다고 보고하였다. 본 연구의 대상 아동 모두 사후 및 유지 평가에서 향상된 형태소 인식 능력과 함께 어휘량의 증가를 나타내었는 점에서 선행 연구와 같은 결과로 해석할 수 있다. Good et al. (2015)은 언어장애로 진단받은 16명의 아동을 대상으로 실시한 형태소 인식 능력 중재 결과, 통제 집단에 비해 중재 대상 아동 들은 철자법과 어휘 능력에서 큰 향상을 보였다고 보고하였다. 또한 대상 아동들은 중재 내용을 일반화하여 단어의 의미를 유 추하였다. 본 연구 결과에서 역시 형태소 인식 능력을 중재한 후 표현 및 수용 어휘의 양적인 증가 효과가 나타나 위 선행 연 구 결과를 지지해주고 있다.

둘째, 중재 후 대상 아동의 학령기언어검사 의미 전체 환산 점수와 백분위가 증가하였다. 이를 통해 중재 후 어휘의 질적 능력이 향상되었음을 알 수 있다. 형태소 인식 능력과 어휘력의 관계를 조사한 Spencer et al.(2015)의 연구 결과, 형태소 인식 능력과 어휘력은 정적인 상관관계가 있다고 하였다. 또한 형태 소 인식 능력의 차이는 어휘량뿐만 아니라 질적 어휘에 영향을 
미친다고 하였다. 이는 본 연구에서 어휘의 양적인 측면뿐만 아 니라 질적 측면에서의 향상이 나타난 결과를 지지해주는 것으 로 볼 수 있다. Baldwin et al.(1982)은 아동이 낱말의 의미 자질 에 대한 지식을 가지고 있을 때 정확하게 비유 문장을 이해하 고 해석한다고 하였다. 즉, 비유 문장을 이해하는 데는 문장을 구성하는 어휘가 중요하다. Jeong(2009)은 읽기 이해에 관여하 는 어휘 능력은 학년이 올라감에 따라 중요성이 커지며 사물 이름대기와 단어 유추가 중요한 변인으로 나타났다고 하였다. 따라서 읽기 이해 부진 학생의 읽기 이해력 향상을 위해서는 어휘의 양적인 측면의 발달을 촉짐함과 더불어 어휘지식의 측 면에 대한 중재가 함께 이루어져야 한다고 하였다.

셋째, 중재 후 대상 아동들의 다형태소단어정의하기평가 점 수가 증가하였다. 단어 정의하기는 대표적인 상위언어 능력이라 고 할 수 있다. 학령기 아동의 보통명사와 추상명사 정의하기 능력을 비교한 $\operatorname{Kim}(2005)$ 의 연구를 살펴보면, 낱말 정의하기 능력은 연령이 증가할수록 발달한다고 한다. Northey(2017)는 형태지식 기반 과제를 제공하는 것이 학령기 아동들의 어휘력 에 긍정적인 영향을 미친다고 보고하였다. 또한, $1 \sim 2$ 학년 아동 들과 6학년 아동들의 단어에 대한 지식을 알아보는 연구(Kieffer \& Lesaux, 2012) 결과, 형태소 인식 능력은 단어와 단어의 관계 이상을 넘어서는 정의 능력을 비롯한 상위언어 능력과 관 련이 있다고 하였다. 교실 상황에서 복합어를 목표로 활동을 실 시하였으며 과제에 사용된 복합어에서 긍정적인 효과뿐만 아니 라 과제에 포함되지 않은 단어로의 일반화가 나타난다고 하였 다. 복합어는 두 개 이상의 형태소가 모여 이루어진 단어이다. 어근과 어근이 결합되어 만들어진 합성어, 어근과 접사로 이루 어진 파생어를 복합어라고 하며 이러한 복합어는 새로운 단어 를 형성하는 조어 과정과 관련되어 있다(Kim, 2014). 합성어와 파생어를 생성하고 의미를 유추하는 형태소 인식 능력은 대표 적인 상위언어 능력이다(Carlisle, 1995). 본 연구의 대상 아동 들이 중재 후 실시된 사후 평가에서 형태소 단위의 의미를 유 추하고 어근과 접사를 이용해 단어를 생성하는 전략을 사용하 는 것이 관찰되었다. 이는 중재 내용을 일반화하여 단어의 의미 를 파악하는 것으로 선행 연구와 같은 결과로 해석할 수 있다. 본 연구의 중재 후 대상 아동 모두 다형태소단어정의하기평가 에서 10 점 이상의 증가를 보였다.

넷째, 중재 후 대상 아동들의 형태소인식능력평가 점수가 증 가하였다. Apel \& Diehm(2014)은 만 6 9세 아동들에게 형태 지식 기반 중재를 실시한 결과, 통제 집단에 비해 중재를 받은 아동들의 형태소 인식 능력이 향상되었다고 하였다. 학령전기 단순언어장애 아동에게 형태지식 기반 중재를 실시한 Mcleod \& Apel (2015)의 연구 결과, 중재 후 대상 아동의 형태소 인식 능력에서 긍정적인 효과가 나타났다. 이와 같이 최근 외국 연구
에서 학령기 아동의 언어 발달에 영향을 미치는 요인으로서 형 태소 인식에 관한 중요성이 논의되고 있다. 본 연구 결과 역시 형태소 인식 능력 향상을 기반으로 한 어휘 중재 결과 어휘의 양적, 질적인 면에서의 향상뿐 아니라 형태소를 인식하고 조작 하는 능력 자체의 향상에도 긍정적인 효과가 있는 것으로 나타 나 위의 선행 연구들과 일치하는 결과를 보고하였다.

Nagy et al.(2003)은 언어장애 위험군인 2, 4학년 학생들의 독해력, 철자 능력, 형태소 인식 능력 등을 연구하였다. 2학년 아동의 경우 형태소 인식 능력과 어휘력이 독해력에 영향을 미 치고 4학년 아동은 형태소 인식 능력이 단어 읽기에 영향을 미 친다고 보고하였다. 언어와 읽기에 어려움을 가진 초등학생을 대상으로 형태지식 기반 중재를 실시한 Wolter \& Dilworth (2014)의 연구 결과에서도 형태지식 기반 중재는 어휘력에 긍정 적인 영향을 미쳤으며 형태소 인식 능력과 읽기 이해에서도 중 재 후 높은 수행력을 나타냈다고 보고하였다. 본 연구에서도 형 태인식 기반 어휘 중재 프로그램을 세 아동에게 적용한 후 어 휘의 양적 증가뿐 아니라 상위언어 능력인 범주어, 반의어, 유의 어의 능력이 향상되었고, 비유 표현이 포함된 비유 문장 이해 능력에서도 긍정적인 효과를 나타냈는데, 이는 단순히 어휘 습 득뿐 아니라 문맥 속에서 문장의 의미를 파악하는 능력 면에서 도 향상이 있음을 보여주는 결과라고 해석할 수 있다. 또한 단 어 정의하기 능력에서의 향상 역시 어휘의 의미를 생각하고 이 를 설명하는 담화 형식의 표현에서도 향상을 보였던 것 역시 텍 스트 이해 능력의 기반인 담화 기술의 향상과 긴밀히 관련되어 있음을 가정해 볼 수 있을 것이다. 이러한 결과는 텍스트에서 모르는 의미를 유추하고 이해하는 능력의 향상과 관련될 수 있 으므로 Nagy et al.(2003)과 Wolter \& Dilworth(2014)의 연구 결과를 지지해준다고 할 수 있다.

중심 단어 : 중재·언어학습장애·형태소인식능력·어휘.

\section{Ethical Statement}

This study was approved by the Institutional Review Board of Yongin University of Graduate Studies (IRB 1707-HSR-076-4).

\section{Acknowledgments}

This work is based on a part of the first author's master's thesis from Yongin University.

\section{Declaration of Conflicting Interests}

There are no conflict of interests.

\section{Funding}

This article was supported by Nationl Research Foundation of Korea (NRF-2017S1A5A8021586).

\section{Author Contributions}

Conceptualization: all authors. Formal analysis: Ji-yeong Oh. Funding acquisition: Kyunghee Jung. Methodology: all authors. Supervision: 
Kyunghee Jung. Validation: all authors. Visualization: Ji-yeong Oh. Writing_original draft: Ji-yeong Oh. Writing_review \& editing: Kyunghee Jung. Approval of final manuscript: all authors.

\section{ORCID iDs}

Ji-yeong Oh Kyunghee Jung

https://orcid.org/0000-0002-0855-5014
https://orcid.org/0000-0002-1816-0171

\section{REFERENCES}

Apel, K., Brimo, D., Diehm, E., \& Apel, L. (2013). Morphological awareness intervention with kindergartners and first- and second-grade students from low socioeconomic status homes: A feasibility study. Language, Speech, and Hearing Services in Schools, 44(2), 161-173.

Apel, K. \& Diehm, E. (2014). Morphological awareness intervention with kindergarteners and first and second grade students from low SES homes: A small efficacy study. Journal of Learning Disabilities, 47(1), 6575.

Baldwin, R. S., Luce, T. S., \& Readence, J. E. (1982). The impact of subschemata on metaphorical processing. Reading Research Quarterly, 17(4), 528-543.

Bishop, D. V. \& Adams, C. (1992). Comprehension problems in children with specific language impairment: Literal and inferential meaning. Journal of Speech, Language, and Hearing Research, 35(1), 119-129.

Brimo, D. (2016). Evaluating the effectiveness of a morphological awareness intervention: A pilot study. Communication Disorders Quarterly, 38(1), 35-45.

Cain, K. \& Oackhill, J. (2007). Children's Comprehension Problems in Oral and Written Language. New York, NY: The Guilford Press.

Carlisle, J. F. (1995). Morphological awareness and early reading achievement. In Feldman, L. B. (1st ed.). Morphological Aspects of Language Processing (pp. 189-209). Hillsdale, NJ: Lawrence Erlbaum Associates.

Good, J. E., Lance, D. M., \& Rainey. J. (2015). The effects of morphological awareness training on reading, spelling, and vocabulary skills. Communication Disorders Quarterly, 36(3), 142-151.

Heo, H., Kawg, K. M., \& Lee, Y. (2011). The relationship among the reading and writing abilities and oral language skills of school-aged lowachievers in language learning. Communication Sciences and Disorders, 16(1), 23-33.

Hong, B. N. (2002). A study on the Teaching of Lexical Competence based on the Word Formation (dissertation). Seoul: Seoul National University of Education.

Jarad, N. I. (2015). Morphemic analysis increases vocabulary and improves comprehension. Glottodidactica. An International Journal of Applied Linguistics, 42(2), 31-43.

Jeon, S. G. (1996). Meta-Language, Linguistics, Meta-Linguistics. Seoul: Korea University Press.

Jeong, M. (2009). Verbal analogical reasoning skills in poor comprehenders. Communication Sciences and Disorders, 14(3), 275-287.

Jin, Y. S., Kwon, E., \& Lee, Y. (2008). A literature review of language development and language disorders of school-aged children. Communication Sciences and Disorders, 13(4), 594-620.

Jung, K. H. (2014). Morphological awareness and reading ability of schoolaged children from grades 1 to 3. Communication Sciences and Disorders, 19(1), 21-30.

Kang, O, R. \& Lee, C. S. (2011). The effect of graphic organizer on vocabulary and reading comprehension of low-achieving students in reading. The Journal of Korea Elementary Education, 22(1), 201-225.

Kieffer, M. J. \& Lesaux, N. K. (2012). Knowledge of words, knowledge about words: Dimensions of vocabulary in first and second language learners in sixth grade. Reading and Writing, 25(2), 347-373.

Kim, G, H. (2003). Korean Language Education Vocabulary by Grade. Seoul: Pagijong Press.
Kim, H. G. \& Kang, J. S. (2005). A comparison on the story grammar and cohesion shown in telling and writing of normal and language-learning disabled children. Korean Journal of Special Education, 39(4), 43-60.

Kim, I. S. (2005). A Comparison of School-aged children's faculty of ability to define between common noun and abstractive noun (dissertation). Seoul: Graduate School of Social Education, Myongji University.

Kim, M. B. (2014). A Korean literature review of metalinguistic skills in semantics and grammar. Journal Of Speech-Language and Hearing Disorders, 23(3), 61-77.

Kim, S. H. \& Jung, K. H. (2015). Morphological awareness and reading abilities for early elementary school students with poor reading skill. Journal of Speech and Hearing Disorders, 24(2), 35-47.

Kim, Y. T., Hong, K. H., Kim, K. H., Jang, H. S., \& Lee, J. Y. (2009). Receptive and Expressive Vocabulary Test (REVT). Seoul: Seoul Community Rehabilitation Center.

Kwon, M. J. \& Seok, D. (2009). The meta language characteristics of children from multicultural families. Journal of Speech and Hearing Disorders, 18(4), 139-150.

Lee, Y. (2007). Validity and reliability analyses of the language test for school-age children. Communication Sciences and Disorders, 12(4), 569586.

Lee, Y. K., Heo, H. S., \& Jang, S. M. (2015). Language Scale for School aged Children (LSSC). Seoul: Inpsyt.

McBride-Chang, C., Wagner, R., Muse, A., Chow, B., \& Shu, H. (2005). The role of morphological awareness in children's vocabulary acquisition in English. Applied Psycholinguistics, 26(3), 415-435.

Mcleod, A. N. \& Apel, K. (2015). Morphological awareness intervention: Study of a child with a history of speech and language impairment. Communication Disorders Quarterly, 36(4), 208-218.

Nagy, W. E. \& Anderson, R. C. (1984). How many words are there in printed school English? Reading Research Quarterly, 19(3), 304-330.

Nagy, W., Berninger, V., Abbott, R., Vaughan, K., \& Vermeulen, K. (2003). Relationship of morphology and other language skills to literacy skills in at-risk second-grade readers and at-risk fourth-grade writers. Journal of Educational Psychology, 95(4), 730-742.

Northey, M. (2017). Effects of embedded morphological instruction on children's morpho-syntactic production (dissertation). Seattle, WA: University of Washington.

Owens, R. (2012). Language Development: An Introduction. (8th ed.). Boston, MA: Pearson Education.

Park, H. W. (2014). Korea Comprehensive Test of Nonverbal Intelligence-2: K-CTONI-2. Seoul: Mindpress.

Paul, R. \& Norbury, C. F. (2012). Language Disorders from Infancy through Adolescence: Listening, Speaking, Reading, Writing, and Communicating. (4th ed.). St. Louis, MO: Elsevier Mosby.

Pae, S. Y., Kim, M. B., Yoon, H. J., \& Jang, S. M. (2015). Korean Language based Reading Assessment (KOLRA). Seoul: Inpsyt.

Ramirez, G., Walton, P., \& Roberts, W. (2014). Morphological awareness and vocabulary development among kindergarteners with different ability levels. Journal of Learning Disabilities, 47(1), 54-64.

Spencer, M., Muse, A., Wagner, R. K., Foorman, B., Petscher, Y., Schatschneider, C., et al. (2015). Examining the underlying dimensions of morphological awareness and vocabulary knowledge. Reading and Writing, 28(7), 959-988.

Wolter, J. A. \& Dilworth, V. (2014). The effects of a multilinguistic morphological awareness approach for improving language and literacy. Journal of Learning Disabilities, 47(1), 76-85.

Wolter, J. A. \& Gibson, F. E. (2015). Morphological awareness assessment and intervention to improve language and literacy. Seminars in Speech and Language, 36(1), 31-41.

Yang, M. \& Seo, Y. (2009). Correlation analysis on the reading and writing abilities of middle school low achievers. Korea Journal of Learning Disabilities, 6(2), 1-19. 


\section{APPENDICES}

Appendix 1. 형태소인식능력평가 과제 유형(합성유추 의미, 합성유추 무의미 과제)

\begin{tabular}{l} 
“앞의 두 낱말을 이용해서 괄호 안에 들어갈 낱말을 생각해서 적어보세요. 주어진 낱말을 이용해서 생각해야 해요." \\
\hline [연습문제] 빨간 : 빨간꽃 $::$ 파란 : 파란꽃 \\
\hline \\
\hline
\end{tabular}

"다음 낱말은 새로 만들어 내는 말이에요. 앞의 두 낱말을 이용해서 괄호 안에 새로운 낱말을 만들어서 적어보세요.

주어진 낱말을 이용해서 못 들어본 말이나 우리 말에 없는 새로운 단어를 만드는 게임입니다."

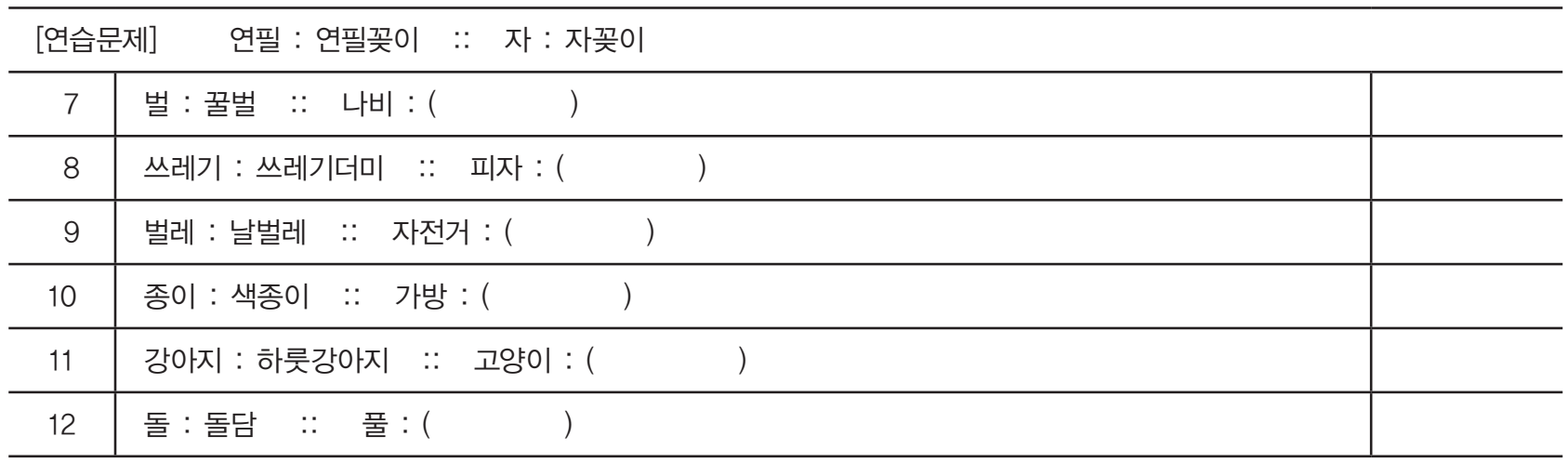




\section{Appendix 2. 파생어 단어 중재 회기 구성의 예}

\begin{tabular}{|c|c|c|}
\hline 단계 & 세부계획 & 시간 \\
\hline & $\begin{array}{l}\text { 1. 치료사와 인사하기 } \\
\text { 예) 치료사: "우리 인사하고 시작할까?" } \\
\text { 아동: "안녕하세요." } \\
\text { 2. 지난 회기에서 배운 내용을 복습하기 }\end{array}$ & 5분 \\
\hline $\begin{array}{l}\text { 파 } \\
\text { 생 } \\
\text { 어 }\end{array}$ & 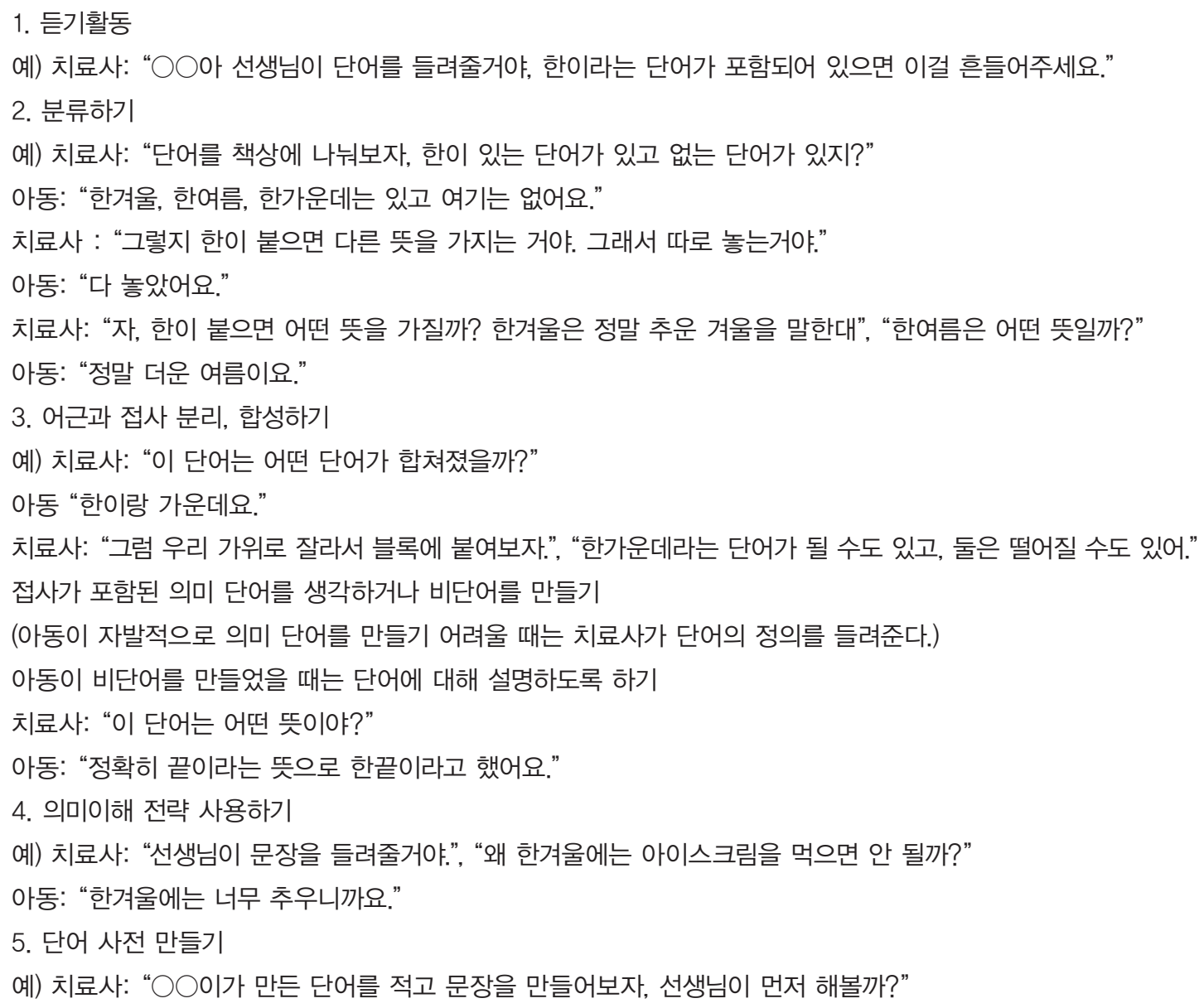 & 30분 \\
\hline 정리 & $\begin{array}{l}\text { 1. 학습한 어휘 확인하기 } \\
\text { 예) 치료사 "우리 오늘 어떤 단어를 배웠지?" } \\
\text { 2. 어휘에 대해 설명하기 } \\
\text { 예) 치료사 "이 단어는 어떤 뜻이었어?", "이 말이 들어가면 단어가 어떻게 변했지?" 등 } \\
\text { 3. 마무리, 인사하기 }\end{array}$ & 5분 \\
\hline
\end{tabular}

